\title{
Antibiofilm activity of papain enzyme against pathogenic Klebsiella pneumoniae
}

\author{
Sara H. Mohamed ${ }^{1,2}$, Mahmoud S. M. Mohamed ${ }^{1 *}$, Mary S. Khalil ${ }^{1}$, Walaa S. Mohamed ${ }^{2}$, Mona I. Mabrouk ${ }^{2}$ \\ ${ }^{1}$ Department of Botany and Microbiology, Faculty of Science, Cairo University, Giza, 12613, Egypt. \\ ${ }^{2}$ Department of Microbiology, National Organization for Drug Control and Research, Giza, Egypt.
}

\begin{tabular}{|c|c|}
\hline ARTICLE INFO & ABSTRACT \\
\hline Article history: & \multirow{5}{*}{$\begin{array}{l}\text { Infections caused by biofilm-embedded pathogens decrease the efficacy of traditional treatments and increase } \\
\text { antibiotic tolerance. Most of the human bacterial infections are biofilm-associated. Therefore, this study aimed to } \\
\text { investigate the antimicrobial as well as the antibiofilm activity of papain enzyme on drug-resistant biofilm producing } \\
\text { Klebsiella pneumoniae. Effect of papain enzyme was tested on Klebsiella pneumonia planktonic cells as well as on } \\
\text { the formation, eradication and cells viability of biofilm. Although no antimicrobial activity of papain enzyme was } \\
\text { detected against planktonic cells, significant biofilm inhibition and eradication were recorded. Biofilm inhibition of } \\
\text { different } K \text {. pneumonia strains ranged from (10.6-56.2\%) at concentration } 50 \mathrm{mg} / \mathrm{mL} \text { and increased to }(21.4-59.0 \%) \text { at } \\
100 \mathrm{mg} / \mathrm{mL} \text { papain. Furthermore, noticeable biofilm eradication was recorded }(7.7-54.9 \%) \text { and }(9.6-55.6 \%) \text { at } 50 \mathrm{mg} / \\
\mathrm{mL} \text { and } 100 \mathrm{mg} / \mathrm{mL} \text { papain concentration respectively. Nevertheless, no significant activity was detected on biofilm } \\
\text { cells viability. Scanning electron microscopy (SEM) confirmed the inhibitory and eradication activity of papain on } K \text {. } \\
\text { pneumoniae biofilm. This study demonstrated for the first time that papain enzyme exerts an antibiofilm effect against } \\
\text { drug-resistant K. pneumoniae, but no antibacterial activity was detected, suggesting its potential application as an } \\
\text { antibiofilm agent in combination with traditional antibacterial agents. }\end{array}$} \\
\hline Received on: 24/04/2018 & \\
\hline Accepted on: 19/05/2018 & \\
\hline Available online: $29 / 06 / 2018$ & \\
\hline $\begin{array}{l}\text { Key words: } \\
\text { Biofilm, SEM, Papain, } \\
\text { MDR, Klebsiella } \\
\text { pneumoniae. }\end{array}$ & \\
\hline
\end{tabular}

\section{INTRODUCTION}

Antimicrobial resistance is an emerging global healthcare crisis with significant impact on human health (Jana et al., 2017). The spread of this resistance and the emergence of nosocomial infections caused by resistant bacteria are factors that adversely affect the course, duration and cost of hospitalizations and mortality (Karampatakis et al., 2016). The prevalence of such resistance among Enterobacteriaceae is a threat observed in the last decades (Swathi et al., 2016). Klebsiella is a Gram-negative, non-motile, encapsulated, lactose fermenting, facultative anaerobe belonging to the Enterobacteriaceae family, the second most popular member of the aerobic bacterial flora of the human intestine, and the most common causative agent of nosocomial and community-acquired infections, at which three to seven

\footnotetext{
${ }^{*}$ Corresponding Author

Mahmoud S. M. Mohamed, Department of Botany and Microbiology, Faculty of Science, Cairo University, Giza 12613, Egypt.

E-mail:msaleh@sci.cu.edu.eg
}

percent of hospital-acquired bacterial infections are related to Klebsiella pneumoniae (Khan et al., 2015; Pereira and Vanetti, 2015; Shahraki-Zahedani et al., 2016).

Currently, most bacterial infections $(60-80 \%)$ are linked to microbial biofilm formation, a lifestyle in the bacterial community that presents inherent resistance to antibiotics and to host immune defense, and organisms which present in biofilm can be 10-1000 times more resistant to antimicrobials compared to their planktonic stage (Patel et al., 2014; Ribeiro et al., 2016). Capsular polysaccharides, type 1 and type 3 pili, are the most important virulence factors contributing to $K$. pneumoniae pathogenesis, and also found to contribute to biofilm formation (Seifi et al., 2016).

The fact that the natural medicines were found to be much safer than synthetic drugs, has led to a resurgence of scientific interest in their biological effects (da Silva et al., 2010). Plants contain various biologically active compounds such as phenolics, alkaloids, carbohydrates, proteins, essential oils, and enzymes, to mention a few of which have antimicrobial and medicinal activities (Abdelhadi and Mohamed, 2016; Mohamed et 
al., 2017; Mohamed et al., 2018a). Plant proteolytic enzymes have received attention in the field of medicine and biotechnology due to their proteolytic properties, and also have been widely used in the medical-pharmaceutical, cosmetic and other industries (Malek et al., 2016).

Papain is an important peptidase enzyme derived from the papaya plant (Carica papaya $\mathrm{L}$ ), including family Caricaceae, known for its proteolytic and anti-inflammatory action and adopted as a topic debridement agent in skin wounds (Gartika et al., 2014; dos Anjos et al., 2016). Usage of papain is indicated for clean and infected wounds at different phases of the healing process (De Siqueira Mota et al., 2015). It is also bactericidal, bacteriostatic, anti-inflammatory and debridement material and shows a broad proteolytic activity against the protein, short chain peptides, amino acid ester and amid (Gartika et al., 2014).

Therefore, we are in need of searching out newer infection-fighting strategies against newer worse strains of pathogenic microbes with higher resistance. This exploration of newer strategies is a global challenge taking by many research institutions, pharmaceutical companies, and academic institutions, because of resistance of pathogens to a commercially available antibiotic (Islam et al., 2015).

According to our previous study we had concluded that among biological enzymes proteolytic enzyme (bromelain) was the best to achieve inhibition and eradication of biofilms of K. pneumoniae (Mohamed et al., 2018b), and considering the proteolytic characteristic described for papain and the biopolymer matrix composition of bacterial biofilms, this study aimed to evaluate the ability of papain to act as an inhibitor for $K$. pneumoniae biofilms in different concentrations.

\section{MATERIALS AND METHODS}

\section{Microbial strains and enzyme}

Ten biofilm-producing multi-drug resistant (MDR) $K$. pneumoniae strains from our previous study were used (Mohamed et al., 2018b). Strains were previously identified by conventional microbiological methods and confirmed by MALDI-TOF/MS using Bruker Biotyper 3.1 software. Antibiotic susceptibility testing was done according to CLSI (2016). Papain from Carica papaya ( $\geq 3 \mathrm{U} / \mathrm{mg}$ ) was obtained from Sigma-Aldrich (St. Louis, USA). Dilutions of papain ranged from 3.125-100 mg/ml.

\section{Effect of papain on planktonic cells}

The bi-fold serial concentrations of papain enzyme (100, $50,25,12.5,6.25$ and $3.125 \mathrm{mg} / \mathrm{mL}$ ) were tested against planktonic cells of $K$. pneumoniae in Mueller-Hinton broth using the broth dilution method according to Doughari and Manzara (2007) with minor modification. In each well of the sterile 96-tissue culture plate, $100 \mu \mathrm{l}$ of bacterial suspension ( $0.5 \mathrm{MacFarland})$ and 100 $\mu 1$ of papain dilution were added and then incubated at $37^{\circ} \mathrm{C}$ for 24 hours. The lowest concentration of enzyme that can inhibit the visible growth of $K$. pneumoniae after overnight incubation considered minimal inhibition concentration (MIC), while the lowest enzyme concentration needed to kill bacteria as defined by the inability to re-culture on agar medium considered as minimum bactericidal concentration (MBC), that was evaluated by plating on Nutrient Agar after incubation at $37^{\circ} \mathrm{C}$ for 24 hours.

\section{Effect of papain on biofilm formation ability}

Inhibition of biofilm formation was assessed using a method mentioned by Nostro et al. (2007) with minor modifications. In each well of sterile 96 tissue culture plate, 100 $\mu \mathrm{l}$ of bacterial suspension ( 0.5 MacFarland) and $100 \mu \mathrm{l}$ of papain dilution were added and then incubated at $37^{\circ} \mathrm{C}$ for 24 hours. After aspiration of planktonic cells, plates are washed twice with phosphate buffer saline (PBS) or sterile saline water and air-dried. Then, $200 \mu \mathrm{l}$ of crystal violet solution (1\%) was added to all wells. After three minutes, the excess dye was removed and plates were washed twice and air dried. The negative control was uninoculated Brain Heart Infusion (BHI) broth, whereas the positive control contained cell cultures alone with no treatment. Biofilm growth was monitored in terms of O.D ${ }_{630} \mathrm{~nm}$ using microplate reader (STAT FAX 2100) in triplicate.

\section{Effect of papain on established biofilms}

The method used was similar to that described by Nostro et al. (2007). After biofilm formation for 24 hours, the medium was discarded, and the wells gently rinsed twice with PBS. A total of $200 \mu \mathrm{l}$ of each treatment concentration were added into the wells. The negative control was biofilm without treatment. After incubation for 24 hours at $37^{\circ} \mathrm{C}$ wells were aspired and the plates are washed twice with phosphate buffer saline or sterile saline water and air-dried. Then, $200 \mu \mathrm{l}$ of crystal violet solution (1\%) was added to all wells. The OD was measured at $630 \mathrm{~nm}$ using a Microplate reader (STAT FAX 2100, USA) in triplicate.

\section{Effect of papain on biofilm cells viability}

Biofilm cell viability assay was done according to the method mentioned by Mah (2014) using BHI broth, to test the ability of biofilm cells to recover after treatment. After formation of the biofilm for 24 hours, the medium was discarded, and the wells gently rinsed twice with PBS. A total of $100 \mu \mathrm{l}$ of each treatment concentration were added into the wells and incubated 24 hours at $37^{\circ} \mathrm{C}$, the $\mathrm{MBC}$ was evaluated by plating on Nutrient Agar after incubation at $37^{\circ} \mathrm{C}, 24$ hours.

\section{Scanning electron microscopy (SEM)}

SEM was employed for investigating the effect of papain enzyme on K. pneumoniae biofilm. Sections of the interior of polystyrene tubes coated with bacterial biofilm were fixed for 2 hours in equal volumes of $4 \%$ glutaraldehyde and $0.2 \mathrm{M}$ cacodylate and washed in equal volumes of $0.4 \mathrm{M}$ saccharose and $0.2 \mathrm{M}$ cacodylate for 2 hours, then post-fixed in $2 \%(\mathrm{w} / \mathrm{v})$ osmium tetroxide and $0.3 \mathrm{M}$ cacodylate for 1 hour. The samples were washed with deionized water and finally dehydrated in ascending grades of ethanol for five minutes each and finally $100 \%$ absolute ethanol for 10 minutes, then examined with Philips XL30 scanning electron microscope (Eindhoven, Netherlands) operated at 20KV (Ansari et al., 2013).

\section{Cluster analysis}

Hierarchical cluster analysis was carried out based on the results of biofilm inhibition and eradication of different $K$. pneumoniae strains at different enzyme concentrations using SPSS software (SPSS Inc. v. 12). The positive results of biofilm inhibition or eradication for each strain were coded as ' 1 ; more 
than $50 \%$ ' and negative results coded as ' 0 ; less than $50 \%$ '. The hierarchical cluster was presented graphically to find the strains that are most similar, clustering of the samples was performed based on average linkage, the branch length represents the distance between the strains.

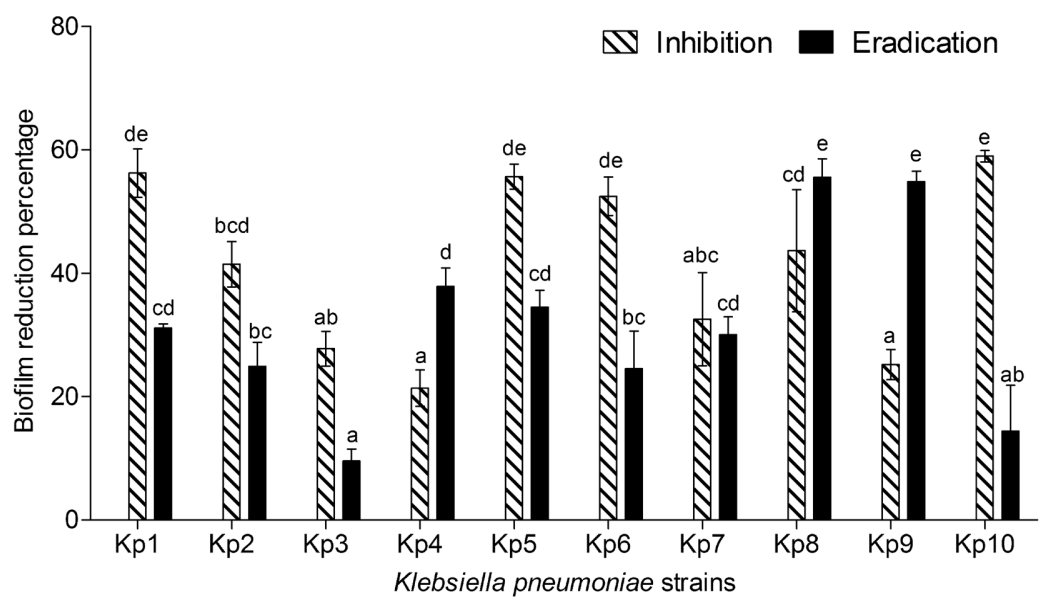

Fig. 1: Biofilm inhibition and eradication percentages of papain enzyme against biofilm-producer Klebsiella pneumoniae strains at concentration $100 \mathrm{mg} / \mathrm{ml}$.

\section{Statistical analysis}

All of the data were analyzed by SPSS statistical software, version 12.0. One-Way ANOVA and a post hoc multiple comparisons (Duncan test) were used to compare the effect of various concentrations of the enzyme on bacterial strains. Values were considered statistically significant at $\mathrm{P}<0.05$. Quantitative variables were expressed as mean \pm standard deviation (SD).

\section{RESULTS AND DISCUSSION}

Recently the most alarming is that bacteria with regular sensitivity to antibiotics are even able to develop a strategy to survive, and the appearance of side effects of antibiotics has led to search for new antimicrobial agents to overcome more disadvantage. Hence, the discovery of anti-infective agents which are active against planktonic microorganisms as well as microbial biofilms represents an ultimate objective (Ayukekbong et al., 2017). Identification of the bacterial strains used in this study was previously confirmed using MALDI-TOF technology, which allows accurate bacterial identification of a large variety of species in reduced time using only a small amount of microbial biomass (De Carolis et al., 2014; Kang et al., 2017).

The current study indicates that no antibacterial effect against planktonic cells was detected when using papain even in high enzyme concentration $(100 \mathrm{mg} / \mathrm{mL})$. In this context, several studies tried to test the antibacterial activity of papain on Grampositive and Gram-negative bacteria, as a novel strategy against bacteria. Lima et al. (2009) verified that papain has no antibacterial activity for E. faecalis, $P$. aeruginosa, S. aureus, $K$. pneumoniae and $S$. typhi indifferent concentrations. In addition, de Oliveira et al. (2014) stated that no antibacterial activity of papain was observed for any isolates of methicillin-resistant $S$. epidermidis and methicillin-resistant $S$. haemolyticus tested, which is in line with our results. In contrast, other study reported that papain has antibacterial activity against Streptococcus mutans (Gartika et al., 2014). Papain was reported to have more significant activity against bacteria than fungi, recorded zone of inhibition against $P$. aeruginosa, B. subtilis, E. coli, and $S$. aureus was 25, 22, 24 and $18 \mathrm{~mm}$, respectively (Seenivasan et al., 2010).

The bacterial ability to adhere and form biofilms on biotic and abiotic surfaces causes an increase in virulence, as well as bacterial pathogenicity, where bacteria in biofilms are already up to thousands of times more resistant to antibiotics when compared to their free-floating, planktonic counterparts (Schroeder et al., 2017). In our study, different biofilm reduction percentage was detected for inhibition and eradication of established biofilms when treated with different concentrations of papain enzymes (Table 1). The best reduction was achieved at the highest enzyme concentrations $100 \mathrm{mg} / \mathrm{ml}$, at which the effect of papain on Klebsiella strains significantly different (Figure 1), causes biofilm inhibition and biofilm eradication ranged from $21.51 \%$ to $58.85 \%$ and $9.45 \%$ to $55.07 \%$, respectively. Followed by enzyme concentration $50 \mathrm{mg} / \mathrm{ml}$, causing biofilm inhibition and biofilm eradication ranged from $11.07 \%$ to $55.99 \%$ and from $7.83 \%$ to $53.82 \%$, respectively (Figure 2). Despite the antibiofilm activity, no effect of biofilm cell viability was detected for any strain. Recently, it was reported that enzymatically active papain induces the immune and/or allergic responses in vitro in human primary keratinocytes through degradation of tight junctional proteins leading to permeabilize the skin barrier (Stremnitzer et al., 2015). On the other hand, clinical studies on Carica papaya aqueous leaf extract with a dose of $2000 \mathrm{mg} / \mathrm{kg}$ body weight indicated no signs of toxicity on tested rats (Halim et al., 2011). Papain enzyme has shown immunomodulatory and anti-inflammatory activities by influencing the levels of inflammatory markers (Mohr and Desser 2013; Pandey et al., 2016). Therefore, papain should be handled with care and more in vivo studies still need to be performed.

Cluster analysis of converted biofilm inhibition and eradication data was performed, and similarities between strains were presented in a dendrogram (Figure 3). The resulting dendrogram showed two main clades. The upper one is comprised of two subclades. K. pneumoniae with different susceptibility are separated alone to the bottom whereas comparable strains 
were clustered together. In this context, the clustering analysis tool was applied to bacterial antibiotic susceptibility to survey the prevalence of known and/or unknown bacterial antibiotic susceptibility and complete phenotypic classification (Berrazeg et al., 2013).

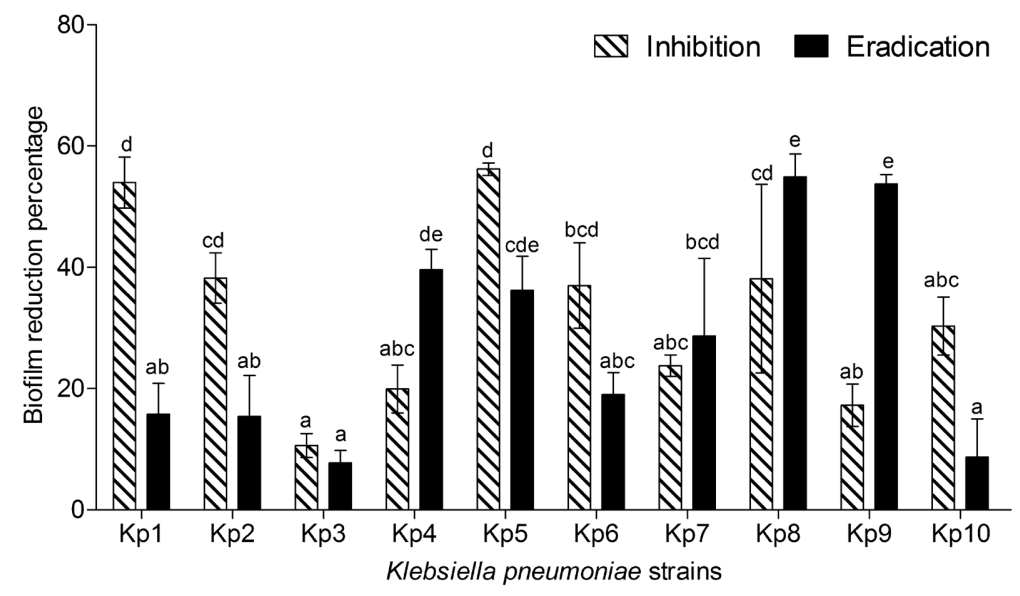

Fig. 2: Biofilm inhibition and eradication percentages of papain enzyme against biofilm-producer Klebsiella pneumoniae strains at concentration $50 \mathrm{mg} / \mathrm{ml}$.

Table 1: Biofilm reduction percentages of Klebsiella pneumoniae by different papain concentrations.

\begin{tabular}{|c|c|c|c|c|c|c|c|c|c|c|c|}
\hline \multirow{2}{*}{$\begin{array}{c}\text { Enzyme } \\
\text { Concentration } \\
(\mathrm{mg} / \mathrm{ml})\end{array}$} & \multirow{2}{*}{$\begin{array}{l}\text { Reduction } \\
\text { percentage }\end{array}$} & \multicolumn{10}{|c|}{ Klebsiella pneumoniae strains } \\
\hline & & Kp1 & Кр2 & Kp3 & Кр4 & Kp5 & Kp6 & Kp7 & Kp8 & Кр9 & Kp10 \\
\hline \multirow{2}{*}{3.125} & $\mathrm{Inh} \% \pm \mathrm{SD}$ & $8.20 \pm 5.21$ & $30.35 \pm 10.32$ & $8.54 \pm 6.40$ & $6.42 \pm 4.48$ & $24.09 \pm 6.06$ & $10.59 \pm 7.76$ & $6.60 \pm 7.46$ & $7.83 \pm 2.13$ & $3.80 \pm 1.74$ & $11.92 \pm 8.36$ \\
\hline & $\mathrm{Era} \% \pm \mathrm{SD}$ & $8.55 \pm 12.25$ & $10.83 \pm 8.26$ & $4.34 \pm 1.96$ & $11.10 \pm 6.57$ & $16.33 \pm 4.65$ & $1.67 \pm 1.08$ & $11.73 \pm 8.01$ & $27.91 \pm 5.24$ & $26.06 \pm 23.10$ & $1.98 \pm 1.24$ \\
\hline \multirow{2}{*}{6.25} & $\mathrm{Inh} \% \pm \mathrm{SD}$ & $8.37 \pm 1.79$ & $32.48 \pm 6.71$ & $9.87 \pm 6.66$ & $7.22 \pm 3.84$ & $28.88 \pm 4.59$ & $11.95 \pm 10.45$ & $10.57 \pm 8.33$ & $7.81 \pm 2.19$ & $5.74 \pm 0.88$ & $17.48 \pm 6.34$ \\
\hline & $\mathrm{Era} \% \pm \mathrm{SD}$ & $14.18 \pm 3.82$ & $12.65 \pm 7.80$ & $6.51 \pm 6.64$ & $22.74 \pm 15.79$ & $25.58 \pm 5.67$ & $4.58 \pm 4.51$ & $10.57 \pm 2.30$ & $39.88 \pm 10.43$ & $42.26 \pm 11.70$ & $2.57 \pm 0.59$ \\
\hline \multirow{2}{*}{12.5} & $\mathrm{Inh} \% \pm \mathrm{SD}$ & $8.72 \pm 2.10$ & $32.58 \pm 9.51$ & $10.73 \pm 4.31$ & $9.61 \pm 4.59$ & $30.68 \pm 4.42$ & $11.74 \pm 8.07$ & $12.61 \pm 4.30$ & $10.64 \pm 1.53$ & $9.31 \pm 1.73$ & $18.73 \pm 10.25$ \\
\hline & $\mathrm{Era} \% \pm \mathrm{SD}$ & $17.75 \pm 4.99$ & $15.19 \pm 9.01$ & $6.17 \pm 3.26$ & $25.15 \pm 4.84$ & $27.49 \pm 12.70$ & $5.37 \pm 2.95$ & $14.87 \pm 5.88$ & $48.18 \pm 4.85$ & $52.12 \pm 2.48$ & $7.03 \pm 5.25$ \\
\hline \multirow{2}{*}{25} & $\mathrm{Inh} \% \pm \mathrm{SD}$ & $14.48 \pm 5.18$ & $37.94 \pm 6.11$ & $11.02 \pm 4.44$ & $20.24 \pm 9.27$ & $50.06 \pm 5.36$ & $31.97 \pm 3.62$ & $23.63 \pm 4.33$ & $10.14 \pm 5.55$ & $15.89 \pm 1.28$ & $18.26 \pm 11.00$ \\
\hline & $\mathrm{Era} \% \pm \mathrm{SD}$ & $22.44 \pm 5.70$ & $15.77 \pm 8.22$ & $8.02 \pm 3.22$ & $29.55 \pm 5.26$ & $34.30 \pm 10.03$ & $5.95 \pm 1.53$ & $16.28 \pm 7.00$ & $53.40 \pm 3.06$ & $53.61 \pm 1.58$ & $8.95 \pm 6.13$ \\
\hline \multirow{2}{*}{50} & $\mathrm{Inh} \% \pm \mathrm{SD}$ & $53.40 \pm 7.26$ & $38.96 \pm 7.18$ & $11.07 \pm 3.45$ & $19.82 \pm 6.80$ & $55.99 \pm 1.81$ & $38.82 \pm 12.22$ & $23.82 \pm 3.09$ & $37.69 \pm 26.95$ & $17.15 \pm 6.01$ & $29.81 \pm 8.24$ \\
\hline & $\mathrm{Era} \% \pm \mathrm{SD}$ & $30.10 \pm 8.83$ & $16.99 \pm 11.73$ & $7.83 \pm 3.53$ & $39.36 \pm 5.81$ & $36.79 \pm 9.72$ & $19.40 \pm 6.29$ & $27.95 \pm 22.26$ & $54.31 \pm 6.53$ & $53.82 \pm 2.68$ & $8.59 \pm 10.88$ \\
\hline \multirow{2}{*}{100} & $\mathrm{Inh} \% \pm \mathrm{SD}$ & $55.74 \pm 6.79$ & $42.27 \pm 6.35$ & $28.36 \pm 4.86$ & $21.51 \pm 5.11$ & $55.90 \pm 3.47$ & $53.08 \pm 5.41$ & $31.97 \pm 13.05$ & $43.38 \pm 17.16$ & $25.15 \pm 4.24$ & $58.85 \pm 1.59$ \\
\hline & $\mathrm{Era} \% \pm \mathrm{SD}$ & $31.12 \pm 1.07$ & $25.84 \pm 6.65$ & $9.45 \pm 3.35$ & $38.20 \pm 5.18$ & $35.13 \pm 4.76$ & $23.91 \pm 10.54$ & $30.07 \pm 5.06$ & $55.07 \pm 5.16$ & $54.94 \pm 2.86$ & $14.24 \pm 12.86$ \\
\hline
\end{tabular}

Kp: Klebsiella pneumoniae strain, Inh\%: Inhibition percentage, Era\%: Eradication percentage, SD: Standard Deviation. All results are presented as averages of results from three independent replicates in three parallel trials.

Because the biofilm matrix is composed of DNA, proteins, and extracellular polysaccharides, recent studies have indicated that the disruption of the biofilm structure could be achieved via the degradation of individual biofilm compounds by various enzymes (Taraszkiewicz et al., 2013), but only a few studies were found to test the inhibitory/eradiation activity of biological enzymes against bacterial biofilms in the literature survey (Mohamed et al., 2018b). Gomaa (2013) tested alphaamylase from Bacillus subtilis and Bacillus cereus against one Klebsiella pneumonia ATCC stain, stating the ability of alphaamylase to inhibit its biofilm by $24.5 \%$ and $19 \%$ respectively. Also, a poor antibiofilm activity of $\beta$-Amylase compared with $\alpha$-Amylase against Staphylococcus aureus was detected by Craigen et al. (2011) in addition to the study done by Kalpana et al. (2012) which stated the inhibitory activity of $\alpha$-amylase of $B$. subtilis against $V$. cholera, $P$. aeruginosa, and MRSA.
SEM was the chosen method for analyzing the surfaces and the morphological changes in the biofilm cells exposed to papain enzyme (Figure 4). Regarding biofilm formation, colonized cells were detected in the untreated biofilm (control) (Figure 4 A), but for biofilm treated with papain, lower number of adhered cells was showed (Figure 4 B-D), confirming the results obtained phenotypically. On the other hand, deformation of $K$. pneumoniae cells was detected in the treated biofilm (Figure $4 \mathrm{D}$ ).

This is the first study to test the antibiofilm activity of papain enzyme against pathogenic $K$. pneumoniae, while in literature there is only one study was found to test antibiofilm activity of papain against biofilms of Staphylococcus species, stated that papain has been demonstrated as a potential product for reducing biofilm of Methicillin-resistant Staphylococcus species (de Oliveira et al., 2014). 


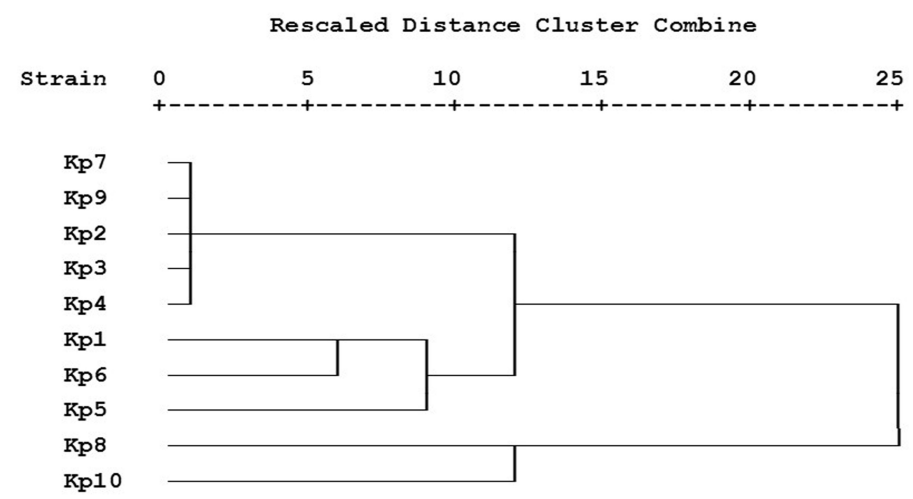

Fig. 3: Hierarchical tree obtained by using data from the biofilm inhibition and eradication percentages of papain enzyme against biofilm-producer Klebsiella pneumoniae strains at different papain concentration.
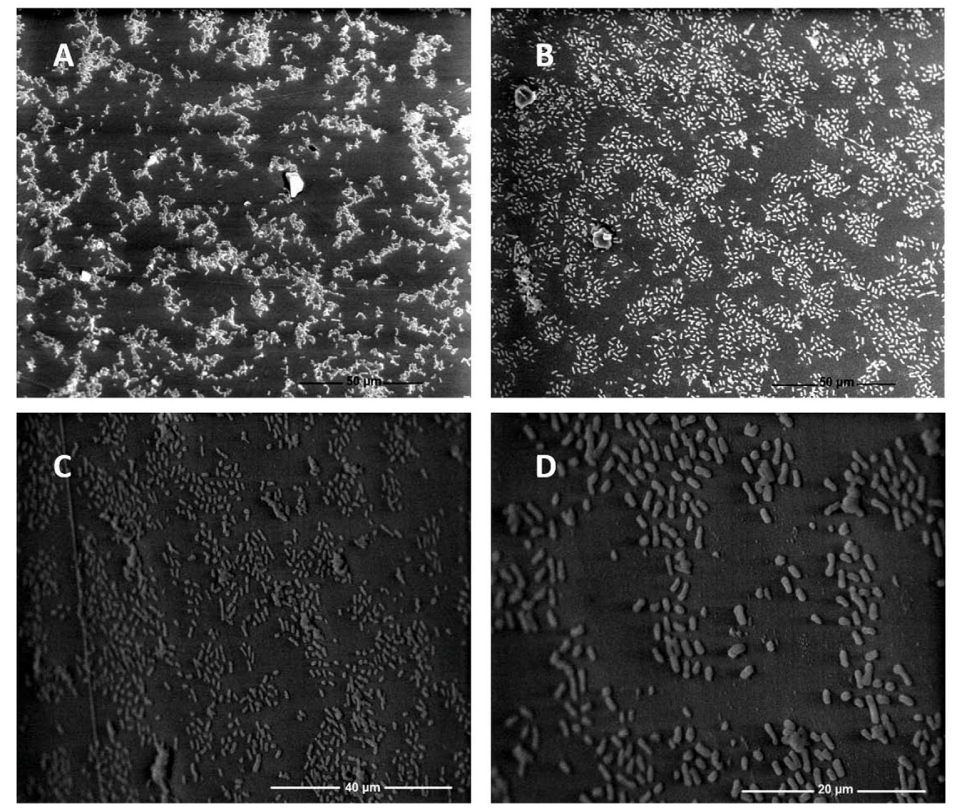

Fig. 4: Scanning Electron Microscopy Imaging (SEM) of Klebsiella pneumoniae biofilm in Brain Heart Infusion (BHI) broth after 24 hours incubation at $37^{\circ} \mathrm{C}$, (A) untreated biofilm at magnification 1600×, (B-D) biofilm treated with $100 \mathrm{mg} / \mathrm{ml}$ papain enzyme at magnification $1600 \times, 3000 \times$ and $6000 \times$.

Nowadays biofilm is considered a major target for the pharmacological development of drugs. Thus, novel biofilm dispersal strategies that can more effectively release biofilmassociated microbes from the protection of the EPS could serve to bolster the arsenal of anti-biofilm therapeutics (Fleming and Rumbaugh, 2017; Mani and Mahalingam, 2017).

\section{CONCLUSION}

Papain enzyme exerts an antibiofilm effect against MDR Klebsiella pneumoniae, but no antibacterial activity was detected. Hence, it may be used as a potential antibiofilm agent in combination with traditional antibacterial agents.

\section{CONFLICT OF INTEREST}

The authors declare that they have no conflict of interests.

\section{REFERENCES}

Abdelhadi AA, Mohamed MSM. Antibacterial and Mutagenic Potency Screening of Different Pomegranate Cultivars Using rep-PCR. J.
Agric. Chem. and Biotechn, 2016; 7(12):297-301.

Ansari MA, Khan HM, Khan AA, Cameotra SS, Pal R. Antibiofilm efficacy of silver nanoparticles against biofilm of extended spectrum $\beta$-lactamase isolates of Escherichia coli and Klebsiella pneumoniae. Appl Nanosci, 2013; 4:859-68.

Ayukekbong JA, Ntemgwa M, Atabe AN. The threat of antimicrobial resistance in developing countries: causes and control strategies. Antimicrob Resist Infect Control, 2017; 6:47.

Berrazeg M, Drissi M, Medjahed L, Rolain J. Hierarchical clustering as a rapid tool for surveillance of emerging antibiotic-resistance phenotypes in Klebsiella pneumoniae strains. J Med Microbiol, 2013; 62(6):864-874. doi:10.1099/jmm.0.049437-0.

Craigen B, Dashiff A, Kadouri DE. The Use of Commercially Available Alpha-Amylase Compounds to inhibit and remove Staphylococcus aureus biofilms. Open Microbiol J, 2011; 5:21-31.

De Carolis E, Vella A, Vaccaro L, Torelli R, Spanu T, Fiori B, Posteraro B, Sanguinetti M. Application of MALDI-TOF mass spectrometry in clinical diagnostic microbiology. J Infect Dev Ctries, 2014; 8:1081-8.

De Siqueira Mota V, Turrini RNT, De Brito Poveda V. Antimicrobial activity of Eucalyptus globulus oil, xylitol and papain: A pilot study. Rev da Esc Enferm, 2015; 49:216-20. 
dos Anjos MM, da Silva AA, de Pascoli IC, Mikcha JM, Machinski M Jr, Peralta RM, de Abreu Filho BA. Antibacterial activity of papain and bromelain on Alicyclobacillus spp. Int J Food Microbiol, 2016; 216:121-6.

Doughari JH, Manzara AM. Studies on the antibacterial activity of root extracts of Carica papaya L. African J Microbiol Res, 2007:37-41.

Fleming D, Rumbaugh K. Approaches to dispersing medical biofilms. Microorganisms, 2017; 5:15.

Gartika M, Sasmita IS, Satari MH, Chairulfattah A, Hilmanto D. Antibacterial activity of papain against Streptococcus mutans ATCC 25175. Int J Dev Res, 2014; 4:2075-7.

Gomaa EZ. Some applications of $\alpha$-amylase produced by Bacillus subtilis NCTC-10400 and Bacillus cereus ATCC 14579 under solid state fermentation. African J Microbiol Res, 2013; 7:3720-9.

Halim SZ, Abdullah NR, Afzan A, Rashid BAA, Jantan I, Ismail Z. Acute toxicity study of Carica papaya leaf extract in Sprague Dawley rats. J Med Plants Res, 2011; 5:1867-72.

Islam A, Ma A, Parvin S, Meh S, Zaman MK, Parvin F, Zaman S, Uddin SM. Evaluation of antibacterial activities of Latex of Caricaceae (Carica Papaya L.). Asian J Pharm Clin Ressearch, 2015; 8:18-21.

Jana B, Cain AK, Doerrler WT, Boinett CJ, Fookes MC, Parkhill $\mathrm{J}$, Guardabassi L. The secondary resistome of multidrug-resistant Klebsiella pneumoniae. Sci Rep, 2017; 7:42483.

Kalpana BJ, Aarthy S, Pandian SK. Antibiofilm activity of $\alpha$-amylase from Bacillus subtilis S8-18 against biofilm forming human bacterial pathogens. Appl Biochem Biotechnol, 2012; 167:1778-94.

Kang L, Li N, Li P, Zhou Y, Gao S, Gao H, Xin W, Wang J. MALDI-TOF mass spectrometry provides high accuracy in identification of Salmonella at species level but is limited to type or subtype Salmonella serovars. Eur J Mass Spectrom, 2017; 23:70-82.

Karampatakis T, Antachopoulos C, Iosifidis E, Tsakris A, Roilides E. Molecular epidemiology of carbapenem-resistant Klebsiella pneumoniae in Greece. Future Microbiol, 2016; 11:809-23.

Khan HA, Ahmad A, Mehboob R. Nosocomial infections and their control strategies. Asian Pac J Trop Biomed, 2015; 5:509-14.

Lima AMB de, Filho E dos SM, Carvalho RG, Junior LC de B. Study in vitro of bactericidal and/or bacteriostatic action of the papaine. A Rev Para Med, 2009; 23.

Mah T-F. Establishing the Minimal Bactericidal Concentration of an Antimicrobial Agent for Planktonic Cells (MBC-P) and Biofilm Cells (MBC-B). J Vis Exp, 2014. DOI: 10.3791/50854.

Malek K, Norazan M, Ramaness P, Othman NZ, Abd Malek R, Aziz R, Aladdin A, El Enshasy H. Cysteine proteases from Carica papaya: An important enzyme group of many industrial applications. IOSR J Pharm Biol Sci Ver I, 2016; 11:11-6.

Mani A, Mahalingam G. Effect of anti-biofilm potential of different medicinal plants: Review. Asian J Pharm Clin Res, 2017; 10:2432.

Mohamed MSM, Abdallah AA, Mahran MH, Shalaby AM Potential alternative treatment of ocular bacterial infections by oil derived from syzygium aromaticum flower (Clove). Curr Eye Res, 2018a. doi: $10 ; 02713683.2018 .1461907$

Mohamed SH, Mohamed MSM, Khalil MS, Azmy M, Mabrouk MI. Combination of essential oil and ciprofloxacin to inhibit/eradicate biofilms in multidrug-resistant Klebsiella pneumoniae. J Appl Microbiol, 2018b. doi: 10.1111/jam.13755.

Mohamed MSM, Saleh AM, Abdel-Farid IB, El-Naggar SA. Growth, hydrolases and ultrastructure of Fusarium oxysporum as affected by phenolic rich extracts from several xerophytic plants. Pestic Biochem Physiol, 2017; 141:57-64.

Nostro A, Roccaro AS, Bisignano G, Marino A, Cannatelli
MA, Pizzimenti FC, Cioni PL, Procopio F, Blanco AR. Effects of oregano, carvacrol and thymol on Staphylococcus aureus and Staphylococcus epidermidis biofilms. J Med Microbiol, 2007; 56:519-23.

de Oliveira HLDCD, Fleming MECK, Silva PV, de Paula GR, Futuro DO, Velarde GC, Esper LMR, Teixeira LA. Influence of papain in biofilm formed by methicillin-resistant Staphylococcus epidermidis and methicillin-resistant Staphylococcus haemolyticus isolates. Brazilian J Pharm Sci, 2014; 50:261-7.

Pandey S, Cabot PJ, Shaw PN, Hewavitharana AK. Antiinflammatory and immunomodulatory properties of Carica papaya. J. Immunotoxicol, 2016; 13(4):590-602.

Patel I, Patel V, Thakkar A, Kothari V. Microbial biofilms: Microbes in social mode. Int J Agric Food Res, 2014; 3:34-49.

Pereira SCL, Vanetti MCD. Potential virulence of Klebsiella sp. isolates from enteral diets. Brazilian J Med Biol Res, 2015; 48:782-9.

Ribeiro SM, Cardoso MH, Cândido EDS, Franco OL. Understanding, preventing and eradicating Klebsiella pneumoniae biofilms. Future Microbiol, 2016; 11:527-38.

Schroeder M, Brooks BD, Brooks AE. The complex relationship between virulence and antibiotic resistance. Genes (Basel), 2017; 8. DOI: 10.3390/genes 8010039 .

Seenivasan R, Roopa L, Geetha S. Investigations on purification, characterization and antimicrobial activity of enzyme papain from Carica papaya Linn. Journal of Pharmacy Research, 2010; 3:1092-5.

Seifi K, Kazemian H, Heidari H, Rezagholizadeh F, Saee Y, Shirvani F, Houri H. Evaluation of biofilm formation among Klebsiella pneumoniae isolates and molecular characterization by ERIC-PCR. Jundishapur J Microbiol, 2016; 9:2-7.

Shahraki-Zahedani S, Moghadampour M, Bokaeian M. Antibiotic resistance pattern of extended-spectrum beta-lactamasesproducing Klebsiella pneumoniae clinical isolates from Zahedan, Southeast Iran. Zahedan J Res Med Sci, 2016; 18. DOI: 10.17795/zjrms-3741.Short.

Shilpa K, Thomas R, Ramyashree A. Isolation and antimicrobial sensitivity pattern of Klebsiella pneumoniae from sputum samples in a tertiary care hospital. Int J Biomed Adv Res, 2016; 7:053-7.

da Silva CR, Oliveira MBN, Motta ES, de Almeida GS, Varanda LL, de Pádula M, Leitão AC, Caldeira-de-Araújo A. Genotoxic and cytotoxic safety evaluation of papain (Carica papaya L.) using in vitro assays. J Biomed Biotechnol, 2010; 2010:1-8.

Stremnitzer C, Manzano-Szalai K, Willensdorfer A, Starkl P, Pieper M, König P, et al. Papain degrades tight junction proteins of human keratinocytes in vitro and sensitizes $\mathrm{C} 57 \mathrm{BL} / 6$ mice via the skin independent of its enzymatic activity or TLR4 activation. J. Invest. Dermatol, 2015; 135(7):1790-800

Swathi CH, Chikala R, Ratnakar KS, Sritharan V. A structural, epidemiological \& genetic overview of Klebsiella pneumoniae carbapenemases (KPCs). Indian J Med Res, 2016; 144:21-31.

Taraszkiewicz A, Fila G, Grinholc M, Nakonieczna J. Innovative strategies to overcome biofilm resistance. Biomed Res Int, 2013; 2013. DOI: $10.1155 / 2013 / 150653$.

The Clinical and Laboratory Standards Institute. Performance Standards for Antimicrobial Susceptibility Testing CLSI Supplement M100-S26, 2016

How to cite this article:

Mohamed SH, Mohamed MSM, Khalil MS, Mohamed WS, Mabrouk MI. Antibiofilm activity of papain enzyme against pathogenic Klebsiella pneumoniae. J App Pharm Sci, 2018; 8(06): 163-168. 